OPEN ACCESS

Edited by:

Goetz Hensel, Leibniz-Institut für Pflanzengenetik und Kulturpflanzenforschung (IPK),

Germany

Reviewed by:

Mickael Malnoy,

Fondazione Edmund Mach, Italy

Eva Stoger,

University of Natural Resources

and Life Sciences, Austria

${ }^{*}$ Correspondence:

Thorben Sprink

Thorben.Sprink@julius-kuehn.de

Specialty section:

This article was submitted to

Plant Biotechnology,

a section of the journal

Frontiers in Plant Science

Received: 28 September 2018

Accepted: 17 December 2018

Published: 14 January 2019

Citation:

Metje-Sprink J, Menz J,

Modrzejewski D and Sprink T (2019) DNA-Free Genome Editing: Past,

Present and Future.

Front. Plant Sci. 9:1957.

doi: 10.3389/fpls.2018.01957

\section{DNA-Free Genome Editing: Past, Present and Future}

\author{
Janina Metje-Sprink, Jochen Menz, Dominik Modrzejewski and Thorben Sprink* \\ AG Genome Editing, Institute for Biosafety in Plant Biotechnology - Julius Kühn-Institut, Quedlinburg, Germany
}

Genome Editing using engineered endonuclease (GEEN) systems rapidly took over the field of plant science and plant breeding. So far, Genome Editing techniques have been applied in more than fifty different plants; including model species like Arabidopsis; main crops like rice, maize or wheat as well as economically less important crops like strawberry, peanut and cucumber. These techniques have been used for basic research as proof-of-concept or to investigate gene functions in most of its applications. However, several market-oriented traits have been addressed including enhanced agronomic characteristics, improved food and feed quality, increased tolerance to abiotic and biotic stress and herbicide tolerance. These technologies are evolving at a tearing pace and especially the field of CRISPR based Genome Editing is advancing incredibly fast. CRISPR-Systems derived from a multitude of bacterial species are being used for targeted Gene Editing and many modifications have already been applied to the existing CRISPR-Systems such as (i) alter their protospacer adjacent motif (ii) increase their specificity (iii) alter their ability to cut DNA and (iv) fuse them with additional proteins. Besides, the classical transformation system using Agrobacteria tumefaciens or Rhizobium rhizogenes, other transformation technologies have become available and additional methods are on its way to the plant sector. Some of them are utilizing solely proteins or protein-RNA complexes for transformation, making it possible to alter the genome without the use of recombinant DNA. Due to this, it is impossible that foreign DNA is being incorporated into the host genome. In this review we will present the recent developments and techniques in the field of DNA-free Genome Editing, its advantages and pitfalls and give a perspective on technologies which might be available in the future for targeted Genome Editing in plants. Furthermore, we will discuss these techniques in the light of existing- and potential future regulations.

Keywords: DNA-free, Genome Editing, RGEN, CRISPR/Cas, CRISPR/Cpf, plant, TALEN, RNPs

\section{INTRODUCTION}

Genome Editing for targeted gene improvement is widely used in the field of plant science for basic research as well as for specific improvement of desired traits in commercial crops. Mainly five tools have been used for targeted Genome Editing so far. Besides Oligonucleotide Directed Mutagenesis (ODM), which had its origin in the early 80 s of the last century and found its way in plant science $\sim 15$ years ago, mainly engineered nuclease (ENs) are used (Wallace et al., 1981). There are four kinds of 
engineered nucleases (i) Zinc-Finger Nucleases, (ii) Meganucleases (iii) Transcription Activator Like Effector Nucleases (TALENs) and (iv) Clustered Regularly Interspaced Short Palindromic Repeats (CRISPR)-Systems. The latter is more a collection of different closely related techniques which all have been adapted for the use in Genome Editing (Puchta, 2017). Nowadays, most applications in plants (and in animals) are done by using either TALENs or CRISPR-Systems. In the majority of cases plants are stable transformed to introduce the Genome Editing tools into the plant genome (Figure 1A). Subsequently the plants are self-pollinated or crossed to get rid of the incorporated DNA, only the intended mutation remains. In some cases, transient expression of the tools e.g., via plasmids, initiate these mutations but all of these techniques make use of recombinant DNA at least in an intermediate step. Lately tools have been developed using solely RNA, preassembled Cas9 protein-gRNA ribonucleoproteins (RNPs) or TALEN-proteins for mutation induction (Figure 1B). All of these are completely free of DNA so the risk of DNA integration into the genome can be excluded. Due to this we will focus on these in the following article.

\section{TARGETED NUCLEASES}

Bacteria have been altering genomes since ages by using e.g., TALEs or CRISPR in combination with CRISPR associated (Cas) nucleases or other techniques such as classical restriction enzymes or Meganucleases (Roberts and Murray, 1976; Jacquier and Dujon, 1985; Stoddard, 2005; Römer et al., 2007). The aims of the bacteria using site-directed nucleases (SDNs) as tools are as diverse as ours, by using altered versions of these natural occurring mechanisms. TALEs e.g., have their origin in Xanthomonas spec. which manipulate cellular processes of the host by introducing TALE-proteins into plant cells via a type III secretion system (Göhre and Robatzek, 2008). Once recognized their target, TALEs alter gene expression e.g., for sugar transporters to supply the bacteria with enough resources to grow which is triggering an infection in the host such as bacterial blight (Lahaye and Bonas, 2001). Scientist revealed the hidden code of these natural occurring tracing devices and fused them with a nuclease (FokI) creating TALE-Nucleases (TALENs) (Boch et al., 2009; Cermak et al., 2011). By using them as pairs a precise induction of a DNA double strand break is possible in many organisms (Sprink et al., 2015).

CRISPR-Systems have a different origin and are ubiquitously present. Around $40 \%$ of bacteria spec. and $90 \%$ of archaea spec. sequenced so far possess one or more CRISPR-Systems (Marraffini and Sontheimer, 2010; Shmakov et al., 2017). They have been described first by Ishino et al., 1987 in the model organism Escherichia coli but it took additional 30 years until their function as a kind of adaptive immune system of bacteria against invading nucleic acids such as plasmids or phages have been revealed in bacteria for yogurt production (Ishino et al., 1987; Barrangou et al., 2007). Today CRISPR is still used in dairy industry to prevent phage infection in starter cultures (Grens, 2015). Additional applications have been derived from this mechanism, Jinek et al. (2012) described the ability of this technology for precise RNA guided genome modification and started the CRISPR-era (Jinek et al., 2012). Their ideas have been adopted by many scientists working in various fields and led to a new age of Genome Editing. Till now hundreds of genomes have been edited in all kinds of kingdoms and clades ranging from small viruses to trees such as Poplar (Fan et al., 2015; Yuan et al., 2015).

Besides the classical Cas9-System from Streptococcus pyogenes several Cas-variants from different species like S.aureus, S.thermophilus and others have been used for Genome Editing in plants (Steinert et al., 2015; Endo et al., 2016). The classical Cas9 System consists of a dual RNA-complex, CRISPR (cr) RNA and trans activating CRISPR (tracr) RNA. Jinek et al. (2012)., fused these two RNAs for easier cloning and handling, creating the single guide RNA (sgRNA), for which multiple vector systems are currently available.

Other systems like the CRISPR/Cpf1 (Clustered Regularly Interspaced Short Palindromic Repeats from Prevotella and Francisella), recently named Cas12a, differ in several aspects from the classical CRISPR/Cas-Systems as (i) the nucleases are smaller (135 vs. $158 \mathrm{kDa}$ ) (ii) the systems possess a natural occurring single guide RNA (iii) cutting of Cas12a results in staggered cuts Cas9 cutting in blunt (iv) the Protospacer adjacent motifs has to be rich in thymine for Cas12a and rich in guanin for Cas9 and (v) the DNA is cut distal from the recognition site by Cas12a and proximal by Cas9.

Cas13 a CRISPR-variant which is able to recognize and cut specific RNA instead of DNA has recently been exploited for RNA editing and tracking in bacteria, mammals and also plants (review Ali et al., 2018). But additional studies have to be performed to test this system for commercial applications. It offers great potential for medicine as well as for agriculture. An initial study in bacterial cells showed non-target, collateral RNA degradation, but these effects have not been reported for recent studies performed in plants and mammals (Cox et al., 2017; Aman et al., 2018).

\section{CURRENT APPLICATIONS}

Currently in several publications' authors promote their work as transgene-free but by taking a closer look at these publications reveal that the status of transgene-freeness focuses only on the end product. In many cases the mutation has been initiated by transient expression of plasmid based CRISPR-DNA or stable integration with subsequent backcrossing. For both techniques, integration of DNA into the host genome is still possible as plasmids are degraded in the cells and could integrate into cut sites (Woo et al., 2015). In this paper we focus on work which has been performed completely without the use of DNA for mutation initiation, meaning either RNA, RGEN RNPs or TALEN- proteins have been used for mutation induction. All of these techniques have been used successfully in plants. DNA-free editing has its origin in editing of animal cell lines or embryos where it is frequently used and is being adapted for more and more species (Hur et al., 2016; Park et al., 2017). DNA-free 


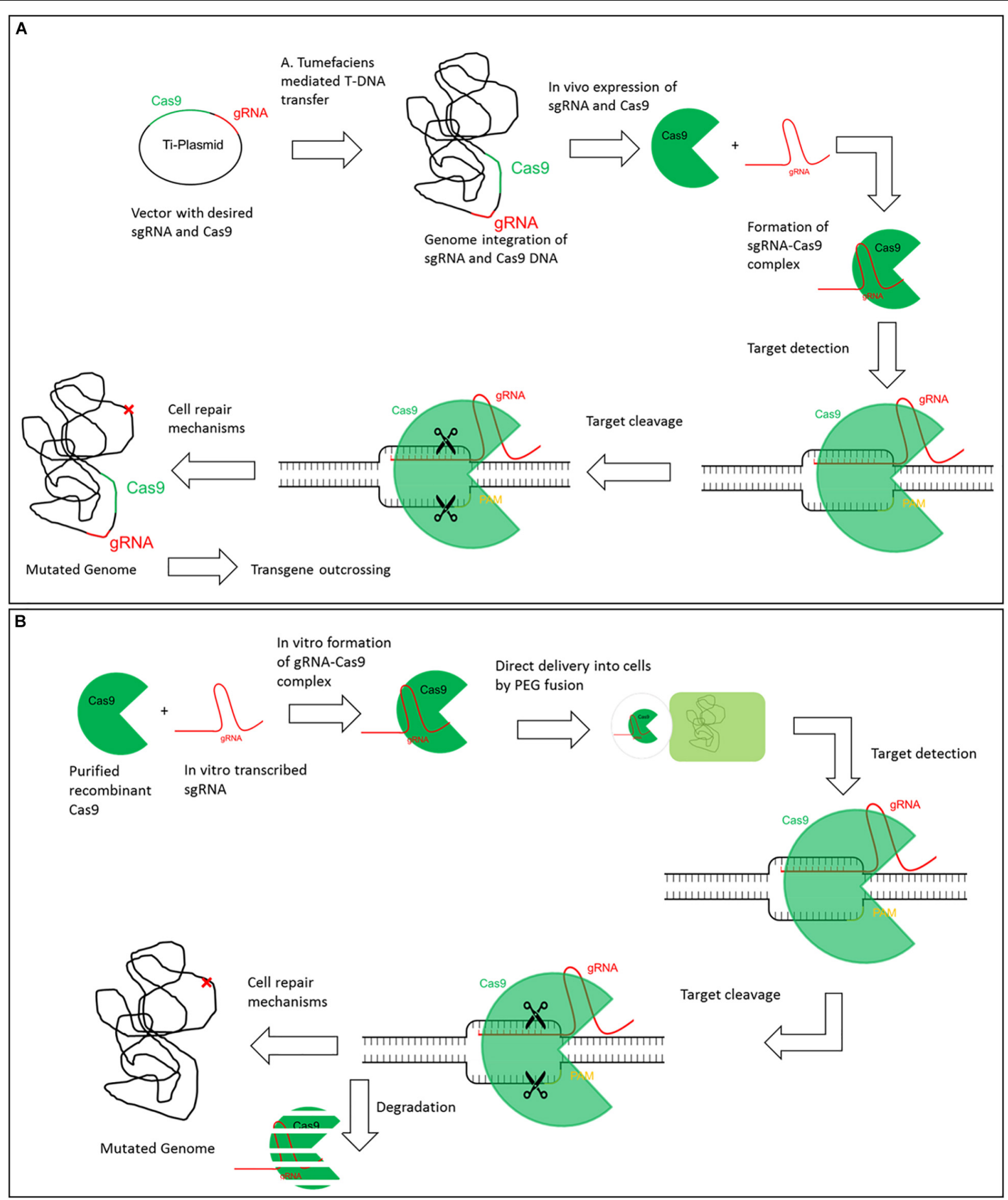

FIGURE 1 | Exemplary comparison of classic CRISPR/Cas9 and DNA-free CRISPR/Cas9. Comparison of classic CRISPR/Cas9 through the example of (A). tumefaciens transformation and DNA-free CRISPR/Cas9 exemplified by PEG mediated protoplast fusion. (A) In the classic CRISPR/Cas9 technique a T-Plasmid is designed that includes the desired gRNA and Cas9 coding sequences. Via Agrobacterium tumefaciens mediated transfer both gRNA and Cas9 sequences can be integrated in the host genome. In vivo gRNA and Cas9 are translated and the gRNA-Cas9 RNP complex is formed. Upon target detection, a double strand break is induced and mutations can arise by internal cell repair mechanisms. The CRISPR/Cas9 complex is constantly expressed and active in the cell. Finally, the genome can contain both the desired mutation and sequences for gRNA and Cas9. The transgene can be outcrossed but this is less practical or even impossible in vegetative propagated crops. (B) For DNA-free CRISPR/Cas9 recombinant Cas9 and in vitro translated gRNA are required. The RNP complex is formed in vitro and is directly delivered to protoplasts by e.g., PEG fusion. The complex is already active and can directly detect its target to induce double strand breaks. Cell repair mechanisms can lead to a mutated genome at the desired target without addition of any foreign DNA. The CRISPR/Cas9 complex is degraded within the cell and no longer available. 
TABLE 1 | Recent publications using DNA-free Genome Editing approaches.

\begin{tabular}{|c|c|c|c|c|c|c|c|c|}
\hline Reference & Plant species & Trait & GE-technique & Tissue & Delivery & Editing efficiency & $\begin{array}{l}\text { Off- } \\
\text { targets }\end{array}$ & Method \\
\hline $\begin{array}{l}\text { Woo et al., } \\
2015\end{array}$ & $\begin{array}{l}\text { Arabidopsis } \\
\text { thaliana, Lactuca } \\
\text { sativa, Nicotiana } \\
\text { attenuata, Oryza } \\
\text { sativa }\end{array}$ & POC & $\begin{array}{l}\text { CRISPR/Cas9 } \\
\text { RNPs }\end{array}$ & Protoplasts & PEG-fusion & $\begin{array}{l}\text { Calli: Monoallelic } \\
\text { mutations: } 5.7 \% \text {; } \\
\text { Biallelic mutations: } \\
40 \%\end{array}$ & $\begin{array}{l}0 / 104 \\
(2-5 \mathrm{MM})\end{array}$ & $\begin{array}{l}\text { Targeted } \\
\text { deep seq. }\end{array}$ \\
\hline $\begin{array}{l}\text { Baek et al., } \\
2016\end{array}$ & $\begin{array}{l}\text { Chlamydomonas } \\
\text { reinhardtii }\end{array}$ & $\begin{array}{l}\text { Yield, abiotic } \\
\text { stress }\end{array}$ & $\begin{array}{l}\text { CRISPR/Cas9 } \\
\text { RNPs }\end{array}$ & Single cells & Electroporation & Cells: Up to $0.56 \%$ & $\begin{array}{l}0 / 17 \\
(2-4 \mathrm{MM})\end{array}$ & $\begin{array}{l}\text { Targeted } \\
\text { deep seq. }\end{array}$ \\
\hline $\begin{array}{l}\text { Malnoy } \\
\text { et al., } 2016\end{array}$ & $\begin{array}{l}\text { Malus domestica, } \\
\text { Vitis vinifera }\end{array}$ & Biotic stress & $\begin{array}{l}\text { CRISPR/Cas9 } \\
\text { RNPs }\end{array}$ & Protoplasts & PEG-fusion & $\begin{array}{l}\text { Protoplasts: } \\
0.1-6.9 \%\end{array}$ & n.d. & n.d. \\
\hline $\begin{array}{l}\text { Stoddard } \\
\text { et al., } 2016\end{array}$ & $\begin{array}{l}\text { Nicotiana } \\
\text { benthamiana }\end{array}$ & $\begin{array}{l}\text { POC, herbicide } \\
\text { resistance }\end{array}$ & TALEN mRNA & Protoplasts & PEG-fusion & $\begin{array}{l}\text { Protoplasts: } \\
\text { No-UTR DNA } \\
\text { control: } 70.5 \% \text {, } \\
\text { No-UTR mRNA } \\
\text { control: } 5.8 \%\end{array}$ & n.d. & n.d. \\
\hline $\begin{array}{l}\text { Subburaj } \\
\text { et al., } 2016\end{array}$ & Petunia hybrid & $\begin{array}{l}\text { Herbicide } \\
\text { resistance }\end{array}$ & $\begin{array}{l}\text { CRISPR/Cas9 } \\
\text { RNPs }\end{array}$ & Protoplasts & PEG-fusion; & $\begin{array}{l}\text { Protoplasts: Cas9 } \\
\text { protein: } \\
\text { 0.03-27.13, } \\
\text { NR-RGEN: } \\
\text { 5.3-34.69 }\end{array}$ & n.d. & n.d. \\
\hline $\begin{array}{l}\text { Zhang } \\
\text { et al., } 2016\end{array}$ & Triticum aestivum & Yield & $\begin{array}{l}\text { CRISPR/Cas9 } \\
\text { mRNA }\end{array}$ & $\begin{array}{l}\text { immature } \\
\text { embryos }\end{array}$ & Biolistics & $\begin{array}{l}\text { No. of } \\
\text { transgen-free } \\
\text { frequency: 0-100\% } \\
\text { No. of homozygous } \\
\text { transgen-free } \\
\text { frequency: } \\
\text { 0-36.8\% }\end{array}$ & $\begin{array}{l}0 / 8 \\
(2-4 \mathrm{MM})\end{array}$ & PCR- RE \\
\hline $\begin{array}{l}\text { Liang et al., } \\
2017\end{array}$ & T. aestivum & Yield & $\begin{array}{l}\text { CRISPR/Cas9 } \\
\text { RNPs }\end{array}$ & $\begin{array}{l}\text { Protoplasts; } \\
\text { immature } \\
\text { embryos }\end{array}$ & $\begin{array}{l}\text { PEG fusion, } \\
\text { Biolistics }\end{array}$ & $\begin{array}{l}\text { Protoplasts: } 33.4 \\
\text { and } 21.8 \% \text { Embryo } \\
\text { cells: gw2-RNPs: } \\
0.18-0.21 \% \\
\text { pGE-TaGW2: } \\
0.99-1 \% \\
\text { gasr7-RNP: } 45.3 \%\end{array}$ & $\begin{array}{l}0 / 20 \\
(2-5 \mathrm{MM})\end{array}$ & $\begin{array}{l}\text { Sanger } \\
\text { seq. }\end{array}$ \\
\hline $\begin{array}{l}\text { Andersson } \\
\text { et al., } 2018\end{array}$ & $\begin{array}{l}\text { Solanum } \\
\text { tuberosum }\end{array}$ & $\begin{array}{l}\text { Starch } \\
\text { syntheses }\end{array}$ & $\begin{array}{l}\text { CRISPR/Cas9 } \\
\text { RNPs }\end{array}$ & Protoplasts & PEG-fusion & Protoplasts: 1-25\% & n.d. & n.d. \\
\hline $\begin{array}{l}\text { Liang et al., } \\
2018\end{array}$ & $\begin{array}{l}\text { T. aestivum, } \\
\text { O. sativa }\end{array}$ & Yield/ POC & $\begin{array}{l}\text { CRISPR/Cas9/ } \\
\text { Cpf1 RNPs, } \\
\text { TALEN-Proteins }\end{array}$ & $\begin{array}{l}\text { Protoplasts; } \\
\text { immature } \\
\text { embryos }\end{array}$ & $\begin{array}{l}\text { PEG fusion, } \\
\text { Biolistics }\end{array}$ & $\begin{array}{l}\text { Protoplasts: } \\
\text { 10.9-33.6\% }\end{array}$ & n.d. & n.d. \\
\hline
\end{tabular}

GE-Technique, Genome editing technique; RNPs, Ribonucleoproteins; WGS, Whole Genome sequencing; POC, Proof of concept; n.d., not determined. 
editing of plants is a new but emerging field which arose 2015, as concerns raised that plants transformed using DNA might be covered by gene technology laws. To date, DNA-free editing is used in at least 14 plant species, to test the ability in proof of concept studies or for improvement of yield or tolerance against biotic and abiotic stress (Table 1). The system is especially useful for species which propagate vegetative or have a long generation cycle as backcrossing is time consuming or impossible such as for potato, grapevine and apple (Table 1; Malnoy et al., 2016; Andersson et al., 2018).

Besides the elimination of DNA integration which circumvents the need for backcrossing and screening of the progeny, the DNA-free systems offer some additional advantages compared to the DNA-based systems as till now no off-target effects (non-target cutting) have been observed neither using targeted nor untargeted approaches for identification (Baek et al., 2016; Shin et al., 2016; Kim et al., 2017). Further advantages are that (i) it can be used without further adaption in a majority of species (even those without established genomic alteration systems) as no coding sequence or promotor have to be adapted (Grahl et al., 2017) (ii) the amount of editors can be controlled in a better way as promotor efficiency is avoided, (iii) the editors are ready to introduce mutations directly after transfection (no lagging phase). Most of these effects seems to be a result of the defined relatively short $(\sim 48 \mathrm{~h})$ persistence of the tools in the targeted organism.

But the systems also have to deal with some drawbacks as to date it is not possible to use it in all species, mainly due to undeveloped or unsuited in vitro techniques. Furthermore, the efficiency is lower compared to classical methods and a selection of positively edited plants is only possible by genomic selection such as sequencing. These points result in higher costs for the technique, but further optimization will result in better in vitro protocols and dropping costs.

\section{TRANSFORMATION METHODS}

DNA-free Genome Editing is currently performed using CRISPR/Cas9 and TALENs and reagents are introduced by either transient expression of mRNAs encoding for TALENs or Cas nuclease and guide RNA or by direct delivery of isolated RNPs. When using RNPs the complex is already preassembled and active upon delivery, when using RNA, the editors have to be transcribed and the complex has to assemble which result in a short delay in activity. DNA-free transformation challenges two major problems: (i) Delivery through the plant cell wall and (ii) regeneration of plants from tissue or cell-wall free cells. To avoid the plant cell wall barrier most edits, use isolated protoplasts, single plant cells which cell wall has been enzymatic digested. Protoplasts were the first tissue which has been used for DNA-free Genome Editing as they can be targeted easily by polyethylene glycol (PEG) mediated fusion. Therefore, the RNP complex or mRNA is enclosed in PEG vesicles and fused with protoplasts. This system enables an average editing rate of around $10 \%$ which is lower compared to DNA-based systems
(Svitashev et al., 2016; Andersson et al., 2018). In potato the system is efficient from the transfection to regenerated plants, it was possible to alter all four copies of a single gene in $2-3 \%$ of the regenerated shoots (Andersson et al., 2018). In other crops such as apple or grapevine the transformation system is working but regeneration protocols for edited lines are still not available as protoplast regeneration and identification of successfully modified lines is tricky and differ even between cultivars of the same species (Malnoy et al., 2016). The single-cell alga Chlamydomonas reinhardtii was successfully transformed with RNPs by electroporation. Although, functional protocols are available for potatoes, lettuce, tobacco, soy and petunia regeneration rate is often low (Woo et al., 2015; Subburaj et al., 2016; Kim et al., 2017). Lately also immature embryos are being used for DNA-free transformation systems. Immature embryos can be target by biolistic delivery of both RNPs and mRNA (Svitashev et al., 2016; Zhang et al., 2016; Liang et al., 2017).

More methods are available to transfer naked DNA to plants but need to be adapted to transform DNA-free Genome Editing tools. Protoplast microinjection is described since 1983 (Griesbach, 1983) and has recently been relighted for DNA delivery in oil palm (Masani et al., 2014) but have not been tested for RNP delivery so far. An optimization of biolistic delivery to plant cells where proteins are loaded into the pores of gold activated mesoporous silica nanoparticles has been described (Martin-Ortigosa and Wang, 2014) but not published for Genome Editing yet. To overcome regeneration of immature cells in planta particle bombardement (iPB) that targets mature plant tissue was introduced in wheat (Hamada et al., 2017). A new method for the transformation of mature plant tissue is infiltration with cell penetrating peptides (CPPs). CPPs are a class of short, positively charged peptides that can translocate across cellular membranes. Recently they have been shown to be capable of binding site-specific nucleases (Rádis-Baptista et al., 2017). Still their potential for DNA-free Genome Editing in plants needs to be exploited.

Additional methods have also been tested to porate single cells and deliver macromolecules to the cell, such as microfluidic cell deformation or sonication and furthermore such as intensive light beams are being discussed but haven't been tested for plants so far (Han et al., 2015; Schlicher et al., 2006).

The field of DNA-free Genome Editing is still evolving and besides new delivery methods for the reagents, proteins coupled to engineered nucleases are being developed. These approaches have been tested and used in stable transformation systems but seem to be also suitable for a DNA-free approach. Besides additional Cas-systems such as Cas12a from different organism also Cas13a could be adapted for a transient RNA-editing in an DNA-free approach, leading to a transient change in expression. This is comparable to the coupling of TALEs and other activators or repressors to Cas9 to alter the expression of genes for a defined time. Furthermore, nickases are frequently used to introduce single stranded DNA breaks in plants, to enhance specificity of Cas-systems (Fauser et al., 2014). Due to the already high specificity of the DNA-free systems, 
nickases are not expected to be used in DNA-free approaches. Likely, other systems will be used in the near future e.g., base editors such as cytidine or adenosine deaminases, which have been used in plants already and offer great potential to be adopted for DNA-free approaches (Gaudelli et al., 2017; Zong et al., 2017). A new and highly discussed approach is to alter methylation or acetylation for Epigenome Editing, these approaches could also be used in DNA-free approaches (Maeder et al., 2013). The newest development in the field is the guidance of integrases by Cas9, to achieve a targeted recombination. This approach is still depended on integrase sites and has been tested only in yeast and mammalian cells but an intensive search for altered integrase sites is ongoing, so that in the future targeted recombination might be possible even in plants (Chaikind et al., 2016; Merrick et al., 2018).

\section{REGULATORY CONCEPTS AND CONCERNS}

Although several European authorities proposed ways, how to handle and interpret new plant breeding technologies in the current or an updated European legal framework (e.g., Advisory Committee on Releases to the Environment [ACRE], 2013; Swedish Board of Agriculture [SBA], 2015; Commissie Genetische Modificatie [COGEM], 2017; Federal office for consumer protection and food safety [BVL] , 2017) the European court of justice (ECJ) decided fairly unscientifically on July 25th this year, that plant products derived from Genome Editing processes (other than modified by chemical or physical mutagenesis) fall under the strict regulatory framework applied for GMOs (ECLI:EU:C:2018:583) ${ }^{1}$. The judgment triggered strong displeasure in the European scientific community, who forecasts noticeable economic disadvantages for European plantand seed industry (European Plant Science Organization [EPSO], 2018; European Seed association [ESA], 2018; Vlaamsche Institute Biologie [VIB], 2018). Additionally, also the Scientific advise mechanism of the European commission published a statement on the ruling in which they recall the productbased aspects of the European gene technology law and recommend "revising the existing GMO Directive to reflect current knowledge and scientific evidence, in particular on gene editing and established techniques of genetic modification" (The Scientific Advice Mechanism [SAM], 2018). Due to the ruling European plant breeders need to undergo expensive and time-consuming approval procedures before their products improved by GEENs can be placed on the market. In particular, for DNA-free Genome Editing approaches, this regulation is intangible due to the lacking difference to a conventionally bred plant, as no DNA from non-related crops or organisms is introduced into the plant genome and detectable, neither in the final plant product, nor in

\footnotetext{
${ }^{1}$ Ruling in the Case C-528/16: http://curia.europa.eu/juris/document/document_ print.jsf?docid $=204387 \&$ text $=\&$ dir $=\&$ doclang $=\mathrm{EN} \&$ part $=1 \&$ occ $=$ first $\&$ mode $=1$ st $\&$ pageIndex $=0 \&$ cid $=5226816$
}

its progenies. At no time-point during generation process, the plant genome encounters foreign, recombinant DNA, which usually triggers current European GMO-regulations. The genome edits are usually indistinguishable from natural mutations (Cao et al., 2011). In addition, off-targets play a minor role in DNA-free approaches: compared with stable and transient expression, GEENs are degraded within hours and thus the GEEN's mode of action is only present in the original cells (protoplasts) of the edited plant (Liang et al., 2015). However, as long Europe sets its focus on the generation process during approval of new plant products, also DNA-free genome edited plants will fall within the same scrutiny as the few legal GMO-plants grown in Europe. This could lead to potential trade issues and impede innovation as stated by members of the WTO lately (World trade organization [WTO], 2018).

Notwithstanding, several countries started to update their legal interpretation of GEEN. Among them are the SouthAmerican ABC: Argentina, Brazil, Chile - the United States, Canada and Israel while in Japan and Australia new regulations and a possible exemption of Genome Editing approaches from strict rulings adopted for conventional genetically modified plants are still under discussion. Giving rise to a worldwide regulatory patchwork for genome-edited plants with a diverse set of interpretations and definitions for genome-edited plants resulting in reservations between international trade partners and trade restraints between economic regions. International harmonization of regulations and definitions thus is essential to close the risk-benefit gap between precaution and innovation potential of genome edited plants (Duensing et al., 2018). Argentina pioneered with a straightforward regulation for the new Genome Editing technologies already in 2015, 2 years after the first application of CRISPR in plants. The Resolución 173/2015 defines a case-by-case dependent approach, in which applicants can request the responsive authority CONABIA already during product development to determine if their products will fall under GMO regulation. Following the Cartagena protocol definitions for living modified organisms; this is only the case when the new plant product contains a -novel- combination of genetic material - similar to conventional transgenic approaches when a transgene is permanently detectable in the final plant product. In case of SDN-1 (NHEJ based deletion/change of a few, often less than 20 nucleotides (Lusser et al., 2011) DNA-free Genome Editing approaches act without introducing foreign DNA that would be detectable in the final plant product. SDN-2 approaches (HDR based replacement of usually less than 20 nucleotides) using a short repair DNA sequence as template, are accordingly not completely DNA-free, although in the final plant product the template is not traceable anymore. In Argentina, plant products derived from GEENs thus will become less strictly regulated than classical GMOs.

${ }^{2}$ Resolución 173/2015: http://www.fao.org/faolex/results/details/en/c/LEX-FAOC 144508 
Likewise, similar guidelines are expectable in Brazil and Chile, which subsequently introduced similar case-by-case, mainly product-focused regulations. Brazil for example interprets GEENs explicitly as SDN as one of several "new precision breeding innovation technologies," which may create a product not considered a GMO in the annex I of the normative resolution no. $16 / 2018^{3}$. Recently, together with the former mentioned $\mathrm{ABC}$, also Paraguay and Uruguay declared their intention to harmonize their Genome Editing-friendly regulations and to establish genome-edited plants analogous to conventionally bred plants ${ }^{4}$. This initiative will transform South America into a hot spot for further Genome Editing innovations. Plant products derived by GEENs still lack on the market in these

\footnotetext{
${ }^{3}$ Resolution no. 16/2018: https://agrobiobrasil.org.br/wp-content/uploads/2018/ 05/Normative-Resolution-16-of-January-15-2018.pdf

${ }^{4}$ XXXVI RO CAS Declaración II: http://consejocas.org/wp-content/uploads/ 2018/09/XXXVI-RO-CAS-Declaraci\%C3\%B3n-II.-T\%C3\%A9cnicas-de-Edici\% C3\%B3n-G\%C3\%A9nica.pdf
}

\section{REFERENCES}

Advisory Committee on Releases to the Environment [ACRE] (2013). Genetically Modified Organisms: New Plant Growing Methods. Available at: https://www.gov.uk/government/uploads/system/uploads/ attachment_data/file/239542/new-techniques-used-in-plant-breeding.pdf (accessed November 20, 2018).

Ali, Z., Mahas, A., and Mahfouz, M. (2018). CRISPR/Cas13 as a tool for RNA interference. Trends Plant Sci. 23, 374-378. doi: 10.1016/j.tplants.2018.03.003

Aman, R., Ali, Z., Butt, H., Mahas, A., Aljedaani, F., Khan, M. Z., et al. (2018). RNA virus interference via CRISPR/Cas13a system in plants. Genome Biol. 19:1. doi: 10.1186/s13059-017-1381-1

Andersson, M., Turesson, H., Olsson, N., Fält, A. S., Ohlsson, P., Gonzalez, M. N., et al. (2018). Genome editing in potato via CRISPR-Cas9 ribonucleoprotein delivery. Physiol. Plant. 164, 378-384. doi: 10.1111/ppl.12731

Baek, K., Kim, D. H., Jeong, J., Sim, S. J., Melis, A., Kim, J.-S., et al. (2016). DNA-free two-gene knockout in Chlamydomonas reinhardtii via CRISPR-Cas9 ribonucleoproteins. Sci. Rep. 6:30620. doi: 10.1038/srep30620

Barrangou, R., Fremaux, C., Deveau, H., Richards, M., Boyaval, P., Moineau, S., et al. (2007). CRISPR provides acquired resistance against viruses in prokaryotes. Science 315, 1709-1712. doi: 10.1126/science.113 8140

Boch, J., Scholze, H., Schornack, S., Landgraf, A., Hahn, S., Kay, S., et al. (2009). Breaking the code of DNA binding specificity of TAL-type III effectors. Science 326, 1509-1512. doi: 10.1126/science.1178811

Cao, J., Schneeberger, K., Ossowski, S., Günther, T., Bender, S., Fitz, J., et al. (2011). Whole-genome sequencing of multiple Arabidopsis thaliana populations. Nat. Genet. 43, 956-963. doi: 10.1038/ng.911

Cermak, T., Doyle, E. L., Christian, M., Wang, L., Zhang, Y., Schmidt, C., et al. (2011). Efficient design and assembly of custom TALEN and other TAL effectorbased constructs for DNA targeting. Nucleic Acids Res. 218:e82. doi: 10.1093/ nar/gkr218

Chaikind, B., Bessen, J. L., Thompson, D. B., Hu, J. H., and Liu, D. R. (2016). A programmable Cas9-serine recombinase fusion protein that operates on DNA sequences in mammalian cells. Nucleic Acids Res. 44, 9758-9770. doi: $10.1093 /$ nar/gkw707

Commissie Genetische Modificatie [COGEM] (2017). CRISPR-Cas En Gerichte Mutagenese Bij Planten. Available at: https://www. cogem.net/showdownload.cfm?objectId=CE6A4585-9BDD-F2300F7FBF2C1B918008\&objectType=mark.hive.contentobjects.download.pdf (accessed November 20, 2018). countries, but it is commendable that more and more countries worldwide clarify their legal status to pave the way for the next green revolution.

\section{AUTHOR CONTRIBUTIONS}

TS, JM-S, and JM wrote the manuscript. DM provided and conducted the data search. JM-S provided and constructed the figure. All authors read and approved the final manuscript.

\section{FUNDING}

JM has received funding from the European Research Council (ERC) under the European Union's Horizon 2020 Research and Innovation Program (Grant Agreement No. 760891). DM acknowledges the funding from the Federal Ministry of Education and Research (BMBF).

Cox, D. B. T., Gootenberg, J. S., Abudayyeh, O. O., Franklin, B., Kellner, M. J., Joung, J., et al. (2017). RNA editing with CRISPR-Cas13. Science 358, 1019-1027. doi: 10.1126/science.aaq0180

Duensing, N., Sprink, T., Parrott, W. A., Fedorova, M., Lema, M. A., Wolt, J. D., et al. (2018). Novel features and considerations for ERA and regulation of crops produced by genome editing. Front. Bioeng. Biotechnol. 6:79. doi: 10.3389/fbioe. 2018.00079

Endo, A., Masafumi, M., Kaya, H., and Toki, S. (2016). Efficient targeted mutagenesis of rice and tobacco genomes using Cpf1 from Francisella novicida. Sci. Rep. 6:38169. doi: 10.1038/srep38169

European Plant Science Organization [EPSO] (2018). First Reaction on the ECJ Ruling regarding mutagenesis and the Genetically Modified Organisms Directive. Available at: http://www.epsoweb.org/webfm_send/2405 (November 20, 2018).

European Seed association [ESA] (2018). Statement on ECJ Ruling C-528/16. Availale at: https://www.euroseeds.eu/system/files/publications/files/esa_18. 0638.pdf (November 20, 2018).

Fan, D., Liu, T., Li, C., Jiao, B., Li, S., Hou, Y., et al. (2015). Efficient CRISPR/Cas9mediated targeted mutagenesis in Populus in the first generation. Sci. Rep. 5:12217. doi: 10.1038/srep 12217

Fauser, F., Schiml, S., and Puchta, H. (2014). Both CRISPR/Cas-based nucleases and nickases can be used efficiently for genome engineering in Arabidopsis thaliana. Plant J. 79, 348-359. doi: 10.1111/tpj.12554

Federal office for consumer protection and food safety [BVL] (2017). Opinion on the Legal Classification of New Plant Breeding Techniques, in particular ODM and CRISPR-Cas9. Available at: http://www.bvl.bund.de/SharedDocs/ Downloads/06_Gentechnik/Opinion_on_the_legal_classification_of_New_ Plant_Breeding_Techniques.pdf?_blob=publicationFile\&v=2 (November 20, 2018).

Ferenczi, A., Pyott, D. E., Xipnitou, A., and Molnar, A. (2017). Efficient targeted DNA editing and replacement in Chlamydomonas reinhardtii using Cpf1 ribonucleoproteins and single-stranded DNA. Proc. Natl. Acad. Sci. U.S.A. 114, 13567-13572. doi: 10.1073/pnas.1710597114

Gaudelli, N. M., Komor, A. C., Rees, H. A., Packer, M. S., Badran, A. H., Bryson, D. I., et al. (2017). Programmable base editing of A.T to G.C in genomic DNA without DNA cleavage. Nature 551:464. doi: 10.1038/nature24644

Göhre, V., and Robatzek, S. (2008). Breaking the barriers: microbial effector molecules subvert plant immunity. Annu. Rev. Phytopathol. 46, 189-215. doi: 10.1146/annurev.phyto.46.120407.110050

Grahl, N., Demers, E. G., Crocker, A. W., and Hogan, D. A. (2017). Use of RNAprotein complexes forgenome editing in non-albicans Candida species. mSphere 2:e00218-17. 
Grens, K. (2015). There's CRISPR in your yogurt: we've all been eating food enhanced by the genome-editing tool for years. Scientist 29. Available at: https: //www.the-scientist.com/notebook/theres-crispr-in-your-yogurt-36142

Griesbach, R. J. (1983). Protoplast microinjection. Plant Mol. Biol. Rep. 1, 32-37. doi: 10.1007/BF02712674

Hamada, H., Linghu, Q., Nagira, Y., Miki, R., Taoka, N., and Imai, R. (2017). An in planta biolistic method for stable wheat transformation. Sci. Rep. 7:11443. doi: 10.1038/s41598-017-11936-0

Han, X., Liu, Z., Jo, M. C., Zhang, K., Li, Y., Zeng, Z., et al. (2015). CRISPR-Cas9 delivery to hard-to-transfect cells via membrane deformation. Sci. Adv. 1, 1-8. doi: 10.1126/sciadv. 1500454

Hur, J. K., Kim, K., Been, K. W., Baek, G., Ye, S., Hur, J. W., et al. (2016). Targeted mutagenesis in mice by electroporation of Cpf1 ribonucleoproteins. Nat. Biotechnol. 34:807. doi: 10.1038/nbt.3596

Ishino, Y., Shinagawa, H., Makino, K., Amemura, M., and Nakata, A. (1987). Nucleotide sequence of the iap gene, responsible for alkaline phosphatase isozyme conversion in Escherichia coli, and identification of the gene product. J. Bacteriol. 169, 5429-5433. doi: 10.1128/jb.169.12.5429-5433. 1987

Jacquier, A., and Dujon, B. (1985). An intron-encoded protein is active in a gene conversion process that spreads an intron into a mitochondrial gene. Cell 41, 383-394. doi: 10.1016/S0092-8674(85)80011-8

Jinek, M., Chylinski, K., Fonfara, I., Hauer, M., Doudna, J. A., and Charpentier, E. (2012). A programmable dual-RNA-guided DNA endonuclease in adaptive bacterial immunity. Science 337, 816-821. doi: 10.1126/science.1225829

Kim, H., Kim, S.-T., Ryu, J., Kang, B.-C., Kim, J.-S., and Kim, S.-G. (2017). CRISPR/Cpf1-mediated DNA-free plantGenome Editing. Nat. Commun. 8:14406. doi: $10.1038 /$ ncomms 14406

Lahaye, T., and Bonas, U. (2001). Molecular secrets of bacterial type III effector proteins. Trends Plant Sci. 6, 479-485. doi: 10.1016/S1360-1385(01)02083-0

Liang, X., Potter, J., Kumar, S., Zou, Y., Quintanilla, R., Sridharan, M., et al. (2015). Rapid and highly efficient mammalian cell engineering via Cas9 protein transfection. J. Biotechnol. 208, 44-53. doi: 10.1016/j.jbiotec.2015.04.024

Liang, Z., Chen, K., Li, T., Zhang, Y., Wang, Y., Zhao, Q., et al. (2017). Efficient DNA-free genome Editing Of Bread Wheat Using CRISPR/Cas9 ribonucleoprotein complexes. Nat. Commun. 8:14261. doi: $10.1038 /$ ncomms 14261

Liang, Z., Chen, K., Zhang, Y., Liu, J., Yin, K., Qiu, J.-L., et al. (2018). Genome editing of bread wheat using biolistic delivery of CRISPR/Cas9 in vitro transcripts or ribonucleoproteins. Nat. Protoc. 13:413. doi: 10.1038/nprot. 2017.145

Lusser, M., Parisi, C., Plan, D., and Rodríguez-Cerezo, E. (2011). New Plant Breeding Techniques. State-of-the-Art and Prospects for Commercial Development. Brussels: Joint Research Centre.

Maeder, M. L., Angstman, J. F., Richardson, M. E., Linder, S. J., Cascio, V. M., Tsai, S. Q., et al. (2013). Targeted DNA demethylation and activation of endogenous genes using programmable TALE-TET1 fusion proteins. Nat. Biotechnol. 31:1137. doi: 10.1038/nbt.2726

Malnoy, M., Viola, R., Jung, M.-H., Koo, O., Kim, S., Kim, J.-S., et al. (2016). DNAfree genetically edited grapevine and apple protoplast using CRISPR/Cas9 ribonucleoproteins. Front. Plant Sci. 7:1904. doi: 10.3389/fpls.2016. 01904

Marraffini, L. A., and Sontheimer, E. J. (2010). CRISPR interference: RNAdirected adaptive immunity in bacteria and archaea. Nat. Rev. Genet. 11:181. doi: $10.1038 / \mathrm{nrg} 2749$

Martin-Ortigosa, S., and Wang, K. (2014). Proteolistics: a biolistic method for intracellular delivery of proteins. Trans. Res. 23, 743-756. doi: 10.1007/s11248014-9807-y

Masani, M. Y. A., Noll, G. A., Parveez, G. K. A., Sambanthamurthi, R., and Prüfer, D. (2014). Efficient transformation of oil palm protoplasts by PEG-mediated transfection and DNA microinjection. PLoS One 9:e96831. doi: 10.1371/journal.pone.0096831

Merrick, C. A., Zhao, J., and Rosser, S. J. (2018). Serine integrases: advancing synthetic biology. ACS Synth. Biol. 7, 299-310. doi: 10.1021/acssynbio.7b0 0308

Park, K.-E., Powell, A., Sandmaier, S. E. S., Kim, C.-M., Mileham, A., Donovan, D. M., et al. (2017). Targeted gene knock-in by CRISPR/Cas ribonucleoproteins in porcine zygotes. Sci. Rep. 7:42458. doi: 10.1038/srep42458
Puchta, H. (2017). Applying CRISPR/Cas for genome engineering in plants: the best is yet to come. Curr. Opin. Plant Biol. 36, 1-8. doi: 10.1016/j.pbi.2016.11.011

Rádis-Baptista, G., Campelo, I. S., Morlighem, J. É. R., Melo, L. M., and Freitas, V. J. (2017). Cell-penetrating peptides (CPPs): from delivery of nucleic acids and antigens to transduction of engineered nucleases for application in transgenesis. J. Biotechnol. 252, 15-26. doi: 10.1016/j.jbiotec.2017.05.002

Roberts, R. J., and Murray, K. (1976). Restriction endonuclease. CRC Crit. Rev. Biochem. 4, 123-164. doi: 10.3109/10409237609105456

Römer, P., Hahn, S., Jordan, T., Strauß, T., Bonas, U., and Lahaye, T. (2007). Plant pathogen recognition mediated by promoter activation of the pepper Bs3 resistance gene. Science 318, 645-648. doi: 10.1126/science.1144958

Schlicher, R. K., Radhakrishna, H., Tolentino, T. P., Apkarian, R. P., Zarnitsyn, V., and Prausnitz, M. R. (2006). Mechanism of intracellular delivery by acoustic cavitation. Ultras. Med. Biol. 32, 915-924. doi: 10.1016/j.ultrasmedbio.2006.02. 1416

Shin, S.-E., Lim, J. M., Koh, H. G., Kim, E. K., Kang, N. K., Jeon, S., et al. (2016). CRISPR/Cas9-induced knockout and knock-in mutations in Chlamydomonas reinhardtii. Sci. Rep. 6:27810. doi: 10.1038/srep27810

Shmakov, S., Smargon, A., Scott, D., Cox, D., Pyzocha, N., Yan, W., et al. (2017). Diversity and evolution of class 2 CRISPR-Cas systems. Nat. Rev. Microbiol. 15, 169-182. doi: 10.1038/nrmicro.2016.184

Sprink, T., Metje, J., and Hartung, F. (2015). PlantGenome editing by novel tools: TALEN and other sequence specific nucleases. Curr. Opin. Biotechnol. 32, 47-53. doi: 10.1016/j.copbio.2014.11.010

Steinert, J., Schiml, S., Fauser, F., and Puchta, H. (2015). Highly efficient heritable plant genome engineering using Cas9 orthologues from Streptococcus thermophilus and Staphylococcus aureus. Plant J. 84, 1295-1305. doi: 10.1111/ tpj. 13078

Stoddard, B. L. (2005). Homing endonuclease structure and function. Quart. Rev. Biophys. 38, 49-95. doi: 10.1017/S0033583505004063

Stoddard, T. J., Clasen, B. M., Baltes, N. J., Demorest, Z. L., Voytas, D. F., Zhang, F., et al. (2016). Targeted mutagenesis in plant cells through transformation of sequence-specific nuclease mRNA. PLoS One 11:e0154634. doi: 10.1371/ journal.pone. 0154634

Subburaj, S., Chung, S. J., Lee, C., Ryu, S.-M., Kim, D. H., Kim, J.-S., et al. (2016). Site-directed mutagenesis in Petunia $\times$ hybrida protoplast system using direct delivery of purified recombinant Cas9 ribonucleoproteins. Plant Cell Rep. 35, 1535-1544. doi: 10.1007/s00299-016-1937-7

Svitashev, S., Schwartz, C., Lenderts, B., Young, J. K., and Cigan, A. M. (2016). Genome editing in maize directed by CRISPR-Cas9 ribonucleoprotein complexes. Nat. Commun. 7:13274. doi: 10.1038/ncomms13274

Swedish Board of Agriculture [SBA] (2015). CRISPR/Cas9 mutated Arabidopsis. Available at: https://www.upsc.se/documents/Information on_interpretation_on_CRISPR_Cas9_mutated_plants_Final.pdf (November 20, 2018).

The Scientific Advice Mechanism [SAM] (2018). Statement by the Group of Chief Scientific Advisors A Scientific Perspective on the Regulatory Status of Products Derived from Gene Editing and the Implications for the GMO Directive. Available at: https://ec.europa.eu/info/sites/info/files/2018_11_gcsa_ statement_gene_editing_2.pdf (November 20, 2018).

Vlaamsche Institute Biologie [VIB] (2018). Regulating Genome Edited Organisms as GMOs Has Negative Consequences for Agriculture, Society and Economy. Available at: http://www.vib.be/en/news/Documents/Position\%20paper\% 20on\%20the\%20ECJ\%20ruling\%20on\%20CRISPR\%2008\%20Nov\%202018_ FINAL.pdf (November 20, 2018).

Wallace, R. B., Schold, M., Johnson, M. J., Dembek, P., and Itakura, K. (1981). Oligonucleotide directed mutagenesis of the human $\beta$-globin gene: a general method for producing specific point mutations in cloned DNA. Nucleic Acids Res. 9, 3647-3656. doi: 10.1093/nar/9.15.3647

Woo, J. W., Kim, J., Kwon, S. I., Corvalan, C., Cho, S. W., Kim, H., et al. (2015). DNA-freeGenome editing in plants with preassembled CRISPRCas9 ribonucleoproteins. Nat. Biotech. 33, 1162-1164. doi: 10.1038/nbt. 3389

World trade organization [WTO] (2018). International Statement on Agricultural Applications of Precision Biotechnology. Available at: https://docs.wto.org/dol2fe/Pages/FE_Search/ExportFile.aspx?id=249267\& filename $=q / G /$ SPS/GEN1658R2.pdf (November 20, 2018). 
Yuan, M., Zhang, W., Wang, J., Al Yaghchi, C., Ahmed, J., Chard, L., et al. (2015). Efficiently editing the Vaccinia virus genome using the CRISPR Cas9 system. J. Virol. 89, 5176-5179. doi: 10.1128/JVI.00339-15

Zhang, Y., Liang, Z., Zong, Y., Wang, Y., Liu, J., Chen, K., et al. (2016). Efficient and transgene-freeGenome editing in wheat through transient expression of CRISPR/Cas9 DNA or RNA. Nat. Commun. 7:12617. doi: 10.1038/ ncomms 12617

Zong, Y., Wang, Y., Li, C., Zhang, R., Chen, K., Ran, Y., et al. (2017). Precise base editing in rice, wheat and maize with a Cas9-cytidine deaminase fusion. Nat. Biotechnol. 35, 438-440. doi: 10.1038/nbt. 3811
Conflict of Interest Statement: The authors declare that the research was conducted in the absence of any commercial or financial relationships that could be construed as a potential conflict of interest.

Copyright $\odot 2019$ Metje-Sprink, Menz, Modrzejewski and Sprink. This is an openaccess article distributed under the terms of the Creative Commons Attribution License (CC BY). The use, distribution or reproduction in other forums is permitted, provided the original author(s) and the copyright owner(s) are credited and that the original publication in this journal is cited, in accordance with accepted academic practice. No use, distribution or reproduction is permitted which does not comply with these terms. 